\title{
Chemical Strategies towards the Synthesis of Betulinic Acid and Its More Potent Antiprotozoal Analogues
}

\author{
André Barreto Cunha ${ }^{1}$, Ronan Batista ${ }^{1, *} \mathbb{C}$, María Ángeles Castro ${ }^{2} \mathbb{1}$ and Jorge Mauricio David ${ }^{1, *}$ \\ 1 Instituto de Química, Universidade Federal da Bahia, Salvador 40170-280, BA, Brazil; andrebarreto@ufba.br \\ 2 Department of Pharmaceutical Sciences, Pharmaceutical Chemistry Section, CIETUS/IBSAL, Faculty of Pharmacy, \\ University of Salamanca, 37007 Salamanca, Spain; macg@usal.es \\ * Correspondence: ronbatis@ufba.br (R.B.); jmdavid@ufba.br (J.M.D.); \\ Tel.: +55-(71)-3283-6841 (R.B.); +55-(71)-3283-6864 (J.M.D.)
}

Citation: Cunha, A.B.; Batista, R.; Castro, M.Á.; David, J.M. Chemical Strategies towards the Synthesis of Betulinic Acid and Its More Potent Antiprotozoal Analogues. Molecules 2021, 26, 1081. https://doi.org/ 10.3390/molecules26041081

Academic Editor: Bartolo Gabriele

Received: 22 January 2021

Accepted: 16 February 2021

Published: 18 February 2021

Publisher's Note: MDPI stays neutral with regard to jurisdictional claims in published maps and institutional affiliations.

Copyright: (C) 2021 by the authors. Licensee MDPI, Basel, Switzerland. This article is an open access article distributed under the terms and conditions of the Creative Commons Attribution (CC BY) license (https:/ / creativecommons.org/licenses/by/ $4.0 /)$.

\begin{abstract}
Betulinic acid (BA, 3 $\beta$-hydroxy-lup-20(29)-en-28-oic acid) is a pentacyclic triterpene acid present predominantly in Betula ssp. (Betulaceae) and is also widely spread in many species belonging to different plant families. BA presents a wide spectrum of remarkable pharmacological properties, such as cytotoxic, anti-HIV, anti-inflammatory, antidiabetic and antimicrobial activities, including antiprotozoal effects. The present review first describes the sources of BA and discusses the chemical strategies to produce this molecule starting from betulin, its natural precursor. Next, the antiprotozoal properties of BA are briefly discussed and the chemical strategies for the synthesis of analogues displaying antiplasmodial, antileishmanial and antitrypanosomal activities are systematically presented. The antiplasmodial activity described for BA was moderate, nevertheless, some C-3 position acylated analogues showed an improvement of this activity and the hybrid modelswith artesunic acid-showed the most interesting properties. Some analogues also presented more intense antileishmanial activities compared with BA, and, in addition to these, heterocycles fused to $\mathrm{C}-2 / \mathrm{C}-3$ positions and amide derivatives were the most promising analogues. Regarding the antitrypanosomal activity, some interesting antitrypanosomal derivatives were prepared by amide formation at the C-28 carboxylic group of the lupane skeleton. Considering that BA can be produced either by isolation of different plant extracts or by chemical transformation of betulin, easily obtained from Betula ssp., it could be said that BA is a molecule of great interest as a starting material for the synthesis of novel antiprotozoal agents.
\end{abstract}

Keywords: betulinic acid; antiprotozoal activities; triterpene acid derivatives; antiplasmodial activity; antileishmanial activity; antitrypanosomal activity

\section{Introduction}

Betulinic acid (BA), namely 3 $\beta$-hydroxy-lup-20(29)-en-28-oic acid, is a pentacyclic lupane-type triterpene (Figure 1) which was allegedly isolated for the first time from the bark of Cornus florida L. (Cornaceae) in 1939. At that time, its structural elucidation was based on data obtained by comparison with a series of synthetic derivatives [1]. Subsequently, BA was also found in the seeds of Zizyphus vulgaris Lam. (var. Spinosus Bunge, Rhamnaceae) [2], in the bark of Platanus acerifolia [3] and in the fibrous outer bark of Syncarpia laurifolia (currently var. glomulifera, Myrtaceae) [4]. For the proper identification of the isolates, the preparation of known chemical derivatives was also necessary. Curiously, it is assumed that BA was found even earlier in other species, but under different trivial names, such as gratiolone (isolated from Gratiola officinalis, Schropulariaceae) [5], platanol and/or platanine (from Platanus spp.) and an unidentified compound obtained from Cornus sanguinea L. and named as "platanoic acid" [3,5-7].

The name "Betulinic acid" has been given to this compound because of its prevalence in birch trees, which belong to the genus Betula, family Betulaceae, especially Betula alba, B. pubescens, B. platyphylla, B. maximowicziana and B. mandshurica. Additionally, although this 
family is the main natural source of BA, this triterpene is spread across many plant species belonging to the families Amaranthaceae, Ancistrocladaceae, Apocynaceae, Asteraceae, Chrysobalanaceae, Convolvuleaceae, Dichapetalaceae, Dilleniaceae, Dioncophyllaceae, Ebenaceae, Ericaceae, Fabaceae, Fagaceae, Lamiaceae, Loganiaceae, Melastomataceae, Moraceae, Myrtaceae, Onagraceae, Ramnaceae, Ranunculaceae, Rhamnaceae, Rosaceae, Rubiaceae, Trochodendraceae, Verbenaceae and Viscaceae [8]. Interestingly, this triterpene can be extracted in large quantities from Akania lucens Hook f. (Akaniaceae), Nerium oleander L. (Apocynaceae), Avicennia marina L. (Verbenaceae), Lemaireocereus spp. (Cactaceae), Arbutus menziesii Pursh. and Arctostaphylos uva-ursi (Ericaceae), Lavandula angustifolia var. officinalis (Lamiaceae), Nuytsia floribunda R. Br. (Loranthaceae), Tectona grandis L. f. (Verbenaceae), Davilla rugosa and other species of Dilleniaceae family (Dillenia, Wormia and Acrotrema). Thus, BA may be considered as a chemotaxonomic marker for these families/genera [9-11]. This compound seems to be biosynthesized from lupeol (LU, Figure 1) by the cytochrome CYP716A12, which has been characterized as a multifunctional enzyme showing lupeol 28-oxidase activities. The same cytochrome is responsible for the methyl C-28 oxidation of $\beta$ - and $\alpha$-amirins, providing, in addition to BA, the other common triterpenes olenanolic (OA) and ursolic (UA) acids (Figure 1) [12,13].
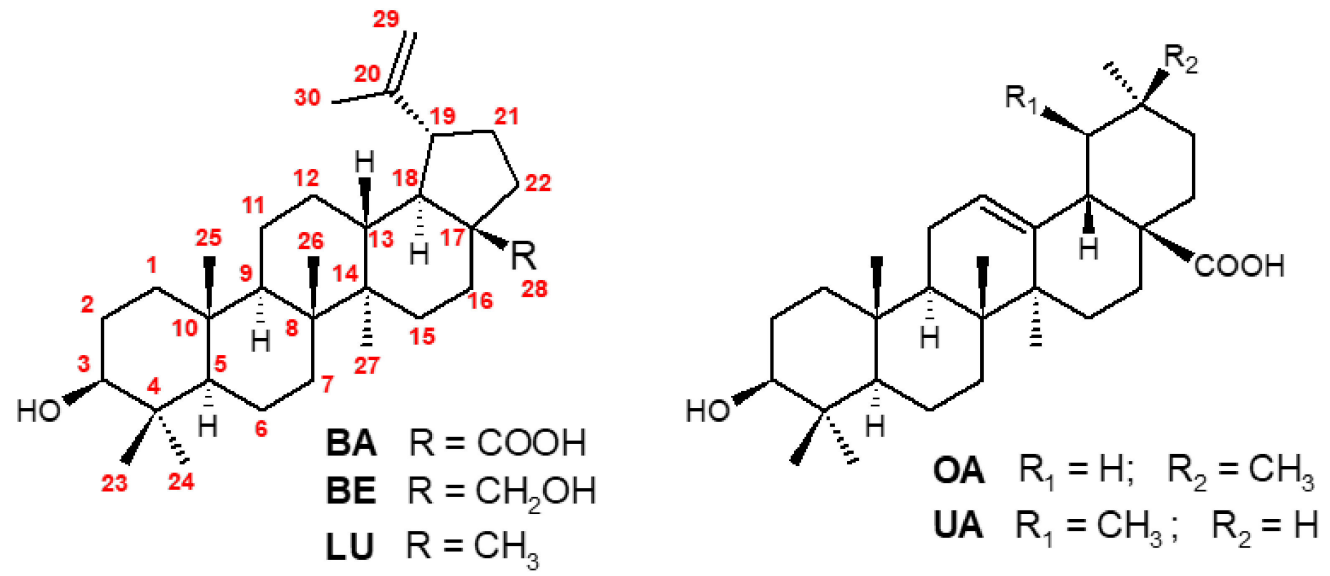

Figure 1. Structures of betulinic acid (BA), betulin (BE), lupeol (LU), oleanolic (OA) and, ursolic (UA) acids.

Only in 1976 the compound's pharmacological importance begin to be evidenced. A study employing plant extracts containing BA exhibited high cytotoxicity and selectivity against lymphocytic leukemia P388 cells [14]. Sequentially, BA was identified as a melanoma-specific cytotoxic compound given that in vivo studies showed tumor growth inhibition without toxicity [15]. Since then, various studies with BA and derivatives as antitumor agents have been published $[16,17]$. Recent investigations have shown that the presence of the carboxyl function at C-28 is required for the cytotoxicity. This conclusion is supported in the fact of BA derivatives are usually significantly more potent than those derived from betulin (BE) (Figure 1) [18]. BA also shows potential as an anti-HIV agent, many of its derivatives, especially hybrids compounds, are highly effective against HIV [19,20]. Compared to azidothymidine (AZT), specific hybrid derivatives presented more potent or equipotent anti-HIV activities but displayed less cytotoxicity [21]. Additionally, numerous studies have been published describing a broad spectrum of other remarkable pharmacological properties for BA against fungi, bacteria, protozoa, diabetes, and inflammatory disorders [22-24]. Among all these potential applications for BA and its analogues, we have focused this review on their antiprotozoal activity, and particularly, on their application to tropical diseases transmitted by vectors.

Vector-borne tropical diseases are disorders that are prevalent in tropical and subtropical regions since the cold season in temperate climates often controls the insect populations (vectors) by forcing their hibernation. Among the most impactful tropical diseases, malaria, 
leishmaniases and trypanosomiases are globally widespread, with potentially harmful consequences if left untreated $[25,26]$.

Malaria is a life-threatening protozoan disease caused by five Plasmodium species (P. falciparum, P. vivax, P. knowlesi, P. ovale and P. malariae) that are transmitted to people through the bites of infected female Anopheles mosquitoes. P. falciparum and P. vivax account for more than $95 \%$ of all human malaria infections and therefore represent a great threat and serious challenge to public health. In 2019, with an estimated 229 million cases and 409,000 deaths, nearly half of the world's population was at risk of malaria. Most cases and deaths occur in sub-Saharan Africa and more severely affect children under 5 years old [27].

In turn, the leishmaniases are a group of diseases caused by protozoan parasites from more than 20 Leishmania species. These parasites are transmitted to humans by the bite of an infected female phlebotomine sandfly, and then three main forms of the disease may arise: cutaneous leishmaniasis (CL), the most common form; visceral leishmaniasis (VL), also known as kala-azar, the most severe form; and mucocutaneous leishmaniasis (MCL), the most disabling form of the disease. More than 1 billion people live in areas endemic for leishmaniasis and are at risk of infection. An estimated 30,000 new cases of VL and more than 1 million new cases of CL occur annually [28,29].

Finally, human trypanosomiasis comprises African trypanosomiasis and Chagas disease which are caused by protozoan parasites of the genus Trypanosoma. African trypanosomiasis is caused by either T. brucei gambiense or T. brucei rhodesiense and threatens some 65 million people in sub-Saharan Africa, especially in rural areas and populations disrupted by war or poverty. Alternatively, Chagas disease is caused by T. cruzi and is responsible for 21,000 deaths per year, occurring mainly in Latin America [29,30].

Since tropical diseases are not very attractive to pharmaceutical companies for the development of novel drugs [31], few options are available on the market to treat these protozoan disorders. Currently, the most effective antimalarial drugs available are chloroquine and artemisinin derivatives, whereas amphotericin B, paromomycin, miltefosine, pentamidine and sodium stibogluconate are the most important antileishmanial agents. Additionally, pentamidine, benznidazole and nifurtimox are the drugs of choice for the treatment of human trypanosomiasis. The problems related to the high economic and social costs of these drugs, along with their toxic effects and the emergence of drug resistance, point to the urgent need for novel antiprotozoal drugs [32].

This review aims to cover all chemical strategies published so far towards the synthesis of BA and its analogues with potent antiprotozoal activities against Plasmodium, Leishmania and Trypanosoma parasites.

\section{Synthesis of BA from Betulin}

In view of the highly valuable potential of BA in the development of novel drugs to treat protozoal and other impacting diseases, it is necessary to establish viable sources of this triterpene to allow for its use as a starting material for the preparation of new and improved bioactive analogues. Within this scenario, it is worth mentioning that promising results regarding the production of $\mathrm{BA}$ and derivatives by biocatalysis and other biotechnological strategies have been widely reported in the literature [33-35] and, therefore, they will not be covered in this review.

To the best of our knowledge, no total synthesis of BA has been reported yet. Although LU, its lupane C-28 methyl co-related triterpene, has been totally synthesized since the 1970s [36,37].

Currently, commercial production of BA substantially depends on traditional phytochemical extraction from birch bark [35], that yields around $0.025 \% w / w$ from dry material [38]. The structure related to BA, is the triterpene alcohol BE (Figure 1), which is much more abundant in birch trees (up to $34 \%$ of the dry barks) [39], but it is biologically less active [38,40] than BA. Therefore, BE could be employed as a starting material to easily prepare BA through semisynthesis, by oxidation of the primary hydroxyl group present at C-28. 
The first reports of the synthesis of BA from BE were published in the late 1930s [1,41]. In this study, the authors used routes with a large number of steps and consequently, the overall yield was low.

Decades later, a classical method was reported using protecting groups to selectively mask the $\mathrm{C}-3 \mathrm{OH}$ group (secondary alcohol) to avoid its isomerization (Scheme 1 ). In this study, although this classical route involves five steps and uses chemical agents that are to both health and the environment (e.g., $\mathrm{CrO}_{3}$ ), $\mathrm{BA}$ could be advantageously produced with high stereoselectivity and a good overall yield [38].
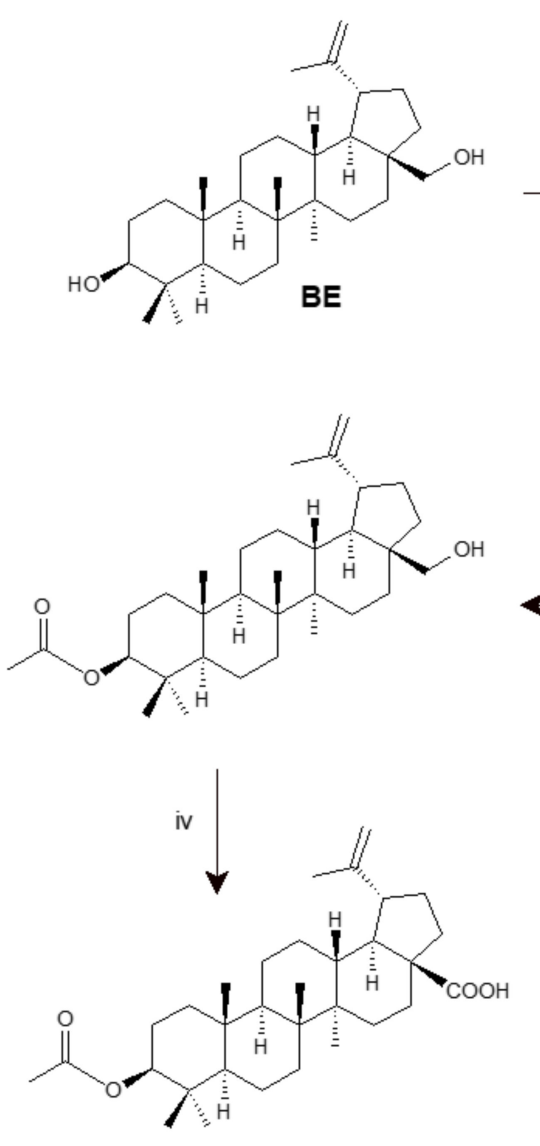
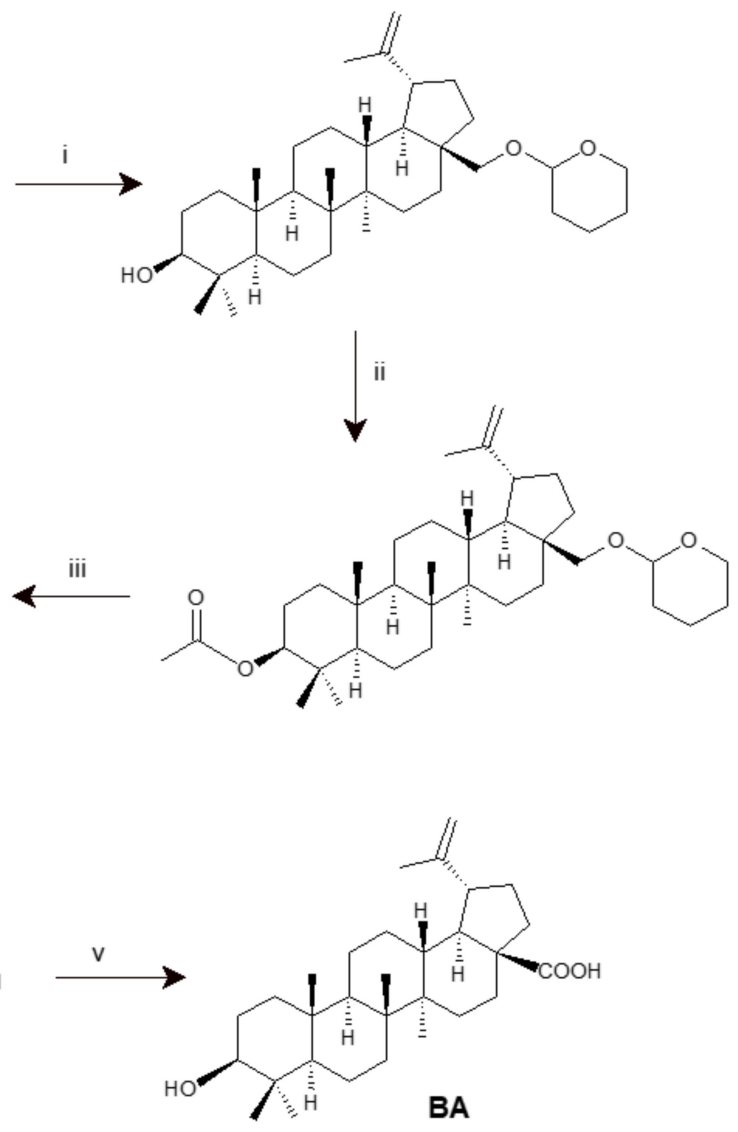

Scheme 1. Synthesis of betulinic acid (BA) from betulin (BE) using protecting groups [38]. Reagents and conditions: (i) DHP/ $\mathrm{CH}_{2} \mathrm{Cl}_{2} /$ PPTS (95\%); (ii) $\mathrm{Ac}_{2} \mathrm{O} /$ pyridine (87\%); (iii) EtOH/PPTS (95\%); (iv) $\mathrm{CrO}_{3} / \mathrm{H}_{2} \mathrm{SO}_{4} /$ acetone $(80 \%) ;(\mathbf{v}) \mathrm{K}_{2} \mathrm{CO}_{3} / \mathrm{MeOH} / \mathrm{H}_{2} \mathrm{O}(88 \%)$.

However, the most common methodology employed to synthesize BA from BE involves a direct Jones oxidation step $\left(\mathrm{CrO}_{3} / \mathrm{H}_{2} \mathrm{SO}_{4} /\right.$ acetone $)$ to form first the intermediate betulonic acid (BoA), with a yield of $90 \%$. Then, BoA is reduced with $\mathrm{NaBH}_{4}$ /2-propanol to obtain, after recrystallization in hot methanol, pure BA. This way, a $3 \beta$-isomer yield of $92 \%$ is obtained (Scheme 2) [42].
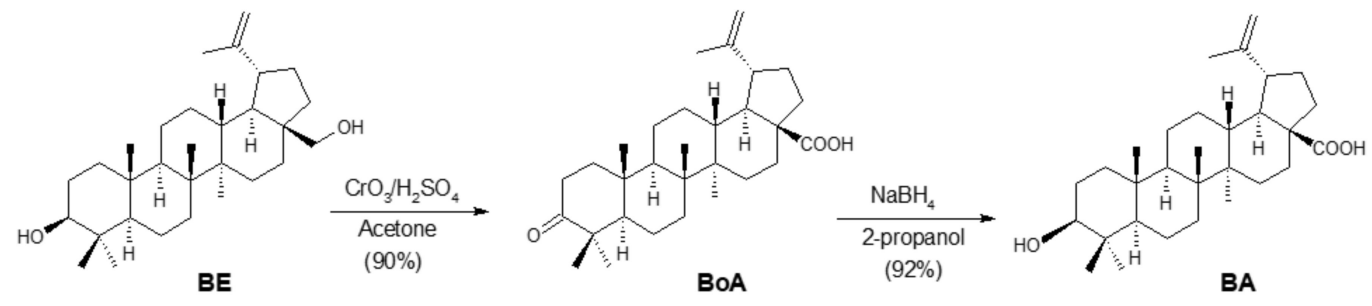

Scheme 2. Synthesis of BA from BE through direct Jones oxidation. 
Recently, a two-step route using solid-supported chromium oxide and potassium permanganate has been suggested to improve BA synthesis [43]. The main step of this approach is the selective oxidation of the primary alcohol function of $\mathrm{BE}$, accomplished with chromic oxide adsorbed on silica gel to obtain BeAL (betulinal) with a reasonable yield $(64 \%)$. Next, the aldehyde derivative is oxidized to BA by potassium permanganate, resulting in a yield of $85 \%$ (Scheme 3 ).

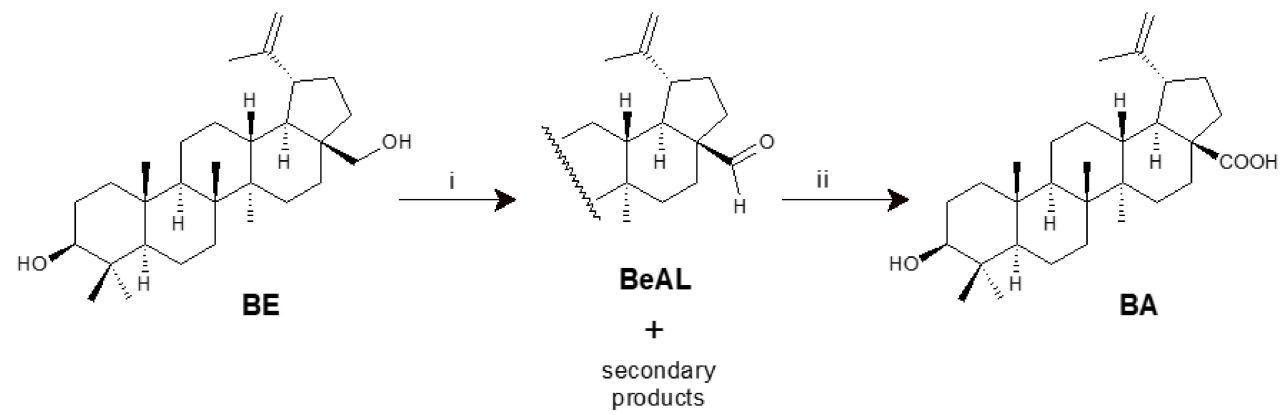

Scheme 3. Synthesis of $\mathrm{BA}$ from $\mathrm{BE}$ via solid-supported $\mathrm{CrO}_{3}$ oxidation [43]. Reagents and conditions: (i) 2 eq. $\mathrm{CrO}_{3} / \mathrm{SiO}_{2}(1: 10)$, toluene, $60 \mathrm{~min}(84 \%)$; (ii) 2 eq. $\mathrm{KMnO} 4$, acetone, $0^{\circ} \mathrm{C}, 30 \mathrm{~min}(\sim 100 \%)$.

All of the above-mentioned approaches were designed to be small-scale preparations, employing more than one synthetic step with overall moderate to good yields. To overcome these limitations, Csuk and collaborators developed the short one-step route represented in Scheme 4 [40]. The method was based on the catalytic conversion of BE into BA, mediated by 4 -acetamide-2,2,6,6-tetramethylpiperidine-1-oxyl (4-acetamide-TEMPO) in a reaction medium containing a mixture of $\mathrm{NaClO}$ and $\mathrm{NaClO}_{2}$ at $35^{\circ} \mathrm{C}$. It is worth mentioning that the simplicity of the synthetic route is the main advantage resulting from this study, in addition to the use of a cheap starting material and, especially, the possibility of obtaining BA on a larger scale, with a yield of $86 \%$ in just one step.

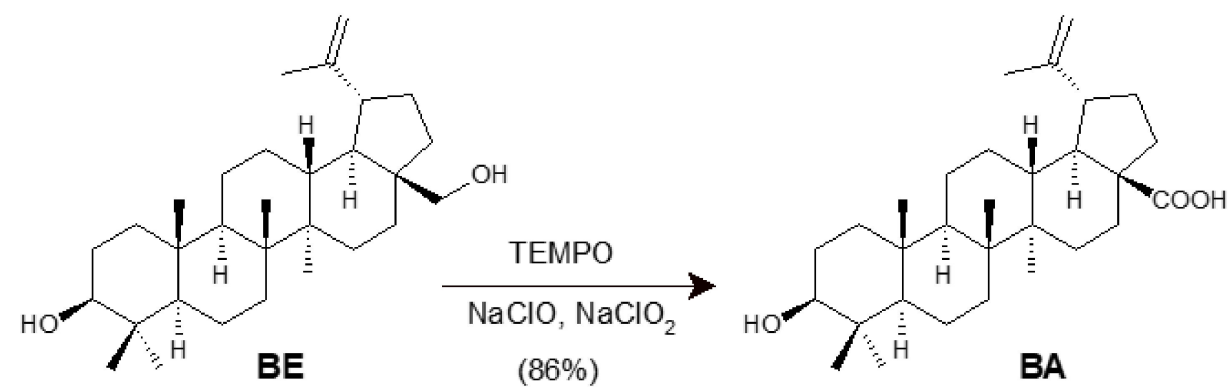

Scheme 4. One-step synthesis of BA from BE via 4-acetamido-TEMPO/ $\mathrm{NaClO} / \mathrm{NaClO}_{2}$.

In a slightly different one-step method, a patented route also employing TEMPO-type catalysts, the hypervalent iodine reagent diacetoxy-iodobenzene (DIB) was used as the oxidizer [44]. The reaction occurs under mild conditions and is both economically and environmentally friendly, with a yield of up to $90 \%$ (Scheme 5).
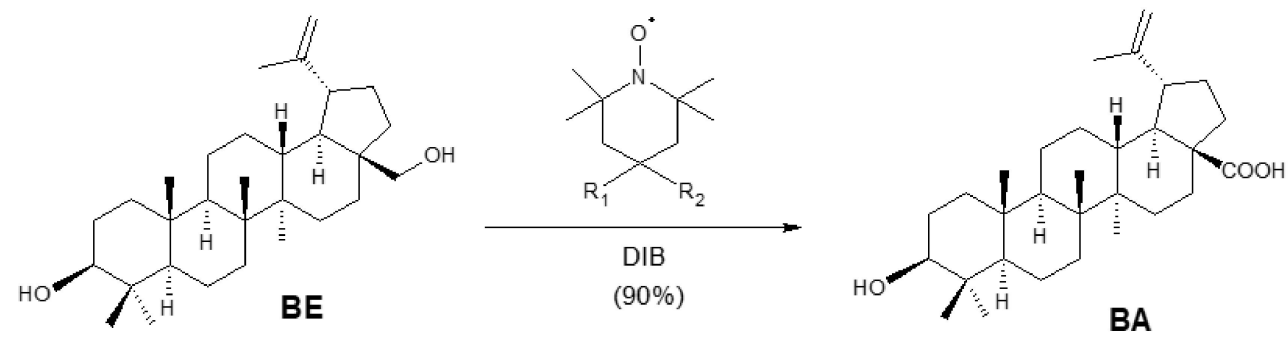

Scheme 5. Synthesis of BA from BE via TEMPO-type catalysts/DIB. 


\section{Synthesis of Antiprotozoal BA Analogues}

Previous studies have shown a vast range of antimicrobial (including antiprotozoal) properties displayed by triterpenes with lupane skeletons [24,45]. These findings are indicative that the BA could be a promising scaffold for several modifications leading to BA derivatives with more potent antiprotozoal activities. Figure 2 offers an overview of the molecular structure of BA, highlighting positions C-2/C-3, C-20/C-29 and C-28 as those susceptible to chemical derivatization. Thus, in recent years several BA analogues have been designed, synthesized and evaluated against parasites Plasmodium sp., Leishmania sp. and Trypanosoma sp. that are described below.

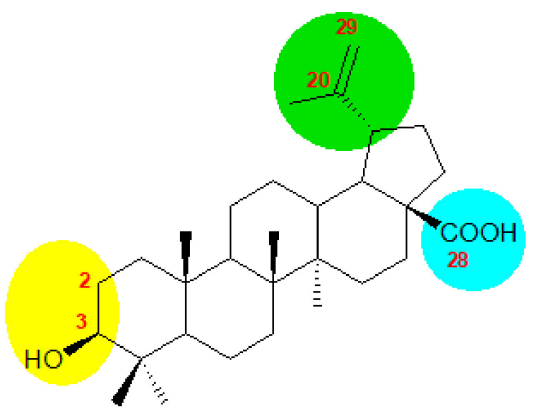

Figure 2. The structural formula of BA and C-2/C-3, C-20/C-29 and C-28 positions amenable to chemical derivatization.

\subsection{Antiplasmodial Analogues}

The in vitro antiplasmodial properties of BA were reported for the first time by Bringmann and collaborators. This study described that BA exhibited moderate to good antimalarial activity in vitro against asexual erythrocytic stages of the human malaria parasite P. falciparum [46].

In a subsequent investigation, the $\mathrm{IC}_{50}$ values for $\mathrm{BA}$ against chloroquine-resistant (K1) and -sensitive (T9-96) strains of P. falciparum were calculated and ranged from 42.9 to $56.7 \mu \mathrm{M}$, respectively [47]. In addition, this study also revealed that BA was ineffective at reducing parasitaemia when tested in vivo in a murine malaria model ( $P$. berghei), even when the highest dosage of $250 \mathrm{mg} / \mathrm{kg} /$ day was used intraperitoneally.

Another interesting study showed that erythrocytes preloaded either with BA or its simple analogues BeAL, LU (1), BE, BA methyl ester (2) and BA amide (3) (Figure 3) did not serve as hosts for P. falciparum parasites [48]. All the above compounds inhibited P. falciparum growth with $\mathrm{IC}_{50}$ values in the range of $7-28 \mu \mathrm{M}$, and this inhibition correlates well with the extent of membrane curvature changes towards stomatocytes or echinocytes in a concentration-dependent approach. The authors concluded that the antiplasmodial activities of BA and its analogues are clearly related to the incorporation of such compounds into the lipid bilayer of erythrocytes, causing modifications of cholesterol-rich membrane rafts that play an important role in parasite vacuolization. The authors also concluded that this established link between erythrocyte membrane modifications and antiplasmodial activity might suggest a novel target for the development of novel antimalarial drugs [48].

The in vitro evaluation of BA and its simple derivatives BoA, betulinic acid acetate (4), BA methyl ester (2) and BA methyl ester acetate (5) (Figure 3) against chloroquineresistant $P$. falciparum parasites showed $\mathrm{IC}_{50}$ values of $9.89,10.01,5.99,51.58$, and $45.79 \mu \mathrm{M}$, respectively [49]. In addition, mice infected with $P$. berghei and treated with 4 showed a dose-dependent reduction in parasitemia. These results are in agreement with those later obtained by Domínguez-Carmona [45], who showed that simple esterification of the C-3 hydroxyl group results in an improvement of the antiplasmodial activity.

Based on studies that reported that piperazine derivatives possess antimalarial action, new piperazinyl derivatives at the C-28 position of 4 [50] were designed and synthesized as prototypes for new antimalarial compounds against the P. falciparum chloroquine-sensitive 
3D7 strain (Scheme 6). Among them, compounds $4\left(\mathrm{IC}_{50}=4 \mu \mathrm{M}\right)$ and $6\left(\mathrm{IC}_{50}=5 \mu \mathrm{M}\right)$ were found to show good antiplasmodial activity, while 7 was shown to be much more potent $\left(\mathrm{IC}_{50}=220 \mathrm{nM}\right)$, also presenting a selectivity index $=18$. However, subsequent in vivo studies [51] revealed that 7 showed toxicity to mice, and docking studies indicated the putative mechanism of action of 7 in inhibiting PfATP6, a SERCA-type Ca+2-ATPase present in P. falciparum, as well as the mammalian SERCA protein with greater affinity, compromising the selectivity expected towards the parasite.

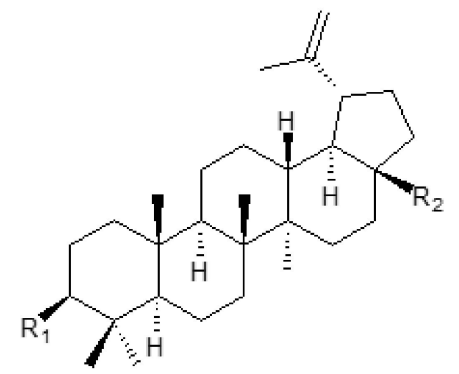

$$
\begin{array}{rll}
\text { BeAL } & \mathrm{R}_{1}=\mathrm{OH} & \mathrm{R}_{2}=\mathrm{CHO} \\
\text { BoA } & \mathrm{R}_{1}=\mathrm{O} & \mathrm{R}_{2}=\mathrm{COOH} \\
\text { BE } & \mathrm{R}_{1}=\mathrm{OH} & \mathrm{R}_{2}=\mathrm{CH}_{2} \mathrm{OH} \\
\mathbf{1} & \mathrm{R}_{1}=\mathrm{OH} & \mathrm{R}_{2}=\mathrm{CH}_{3} \\
\mathbf{2} & \mathrm{R}_{1}=\mathrm{OH} & \mathrm{R}_{2}=\mathrm{COOCH}_{3} \\
\mathbf{3} & \mathrm{R}_{1}=\mathrm{OH} & \mathrm{R}_{2}=\mathrm{CONH}_{2} \\
\mathbf{4} & \mathrm{R}_{1}=\mathrm{OAC} & \mathrm{R}_{2}=\mathrm{COOH} \\
\mathbf{5} & \mathrm{R}_{1}=\mathrm{OAC} & \mathrm{R}_{2}=\mathrm{COOCH} \mathrm{COH}_{3}
\end{array}
$$

Figure 3. Simple antiplasmodial BA analogues.

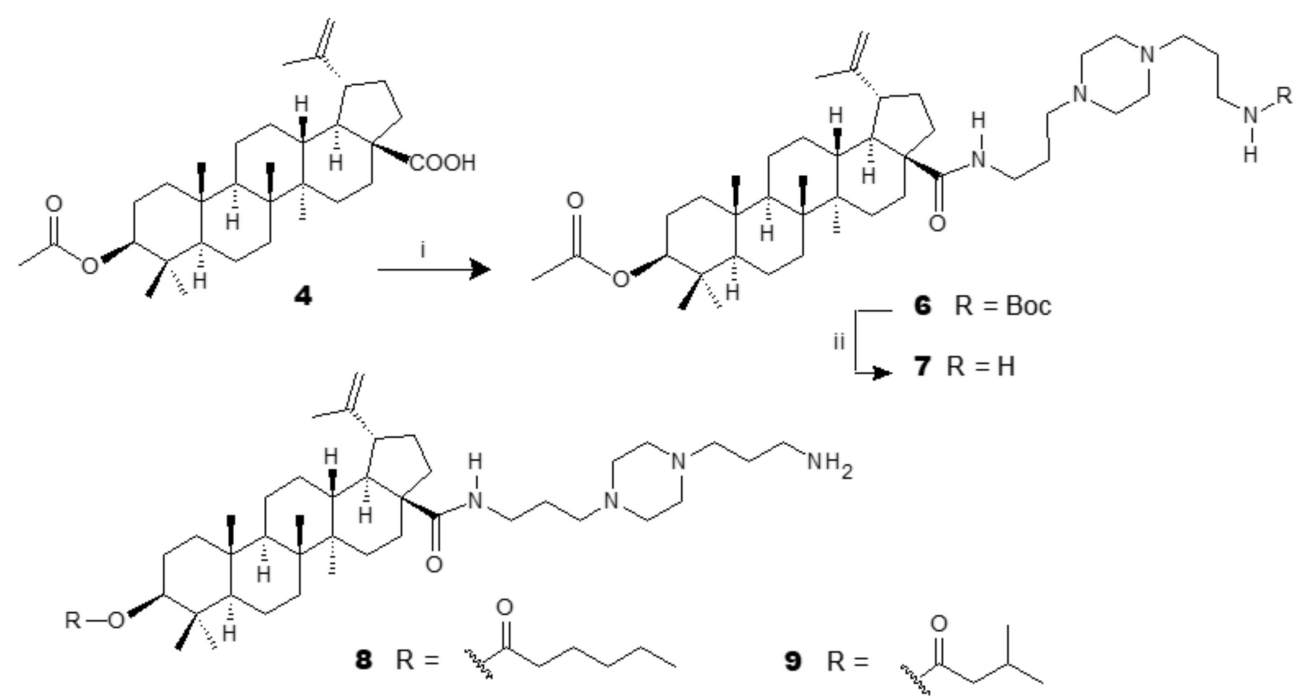

Scheme 6. Synthesis of new piperazinyl derivatives of acetyl betulinic acid. Reagents and conditions: (i) $\mathrm{ClCOCOCl}, 0{ }^{\circ} \mathrm{C}, 3 \mathrm{~h}$; TEA, $N$-tert-butoxycarbonyl-1,4-bis(3-aminopropyl)piperazine, RT, 24 h; (ii) TFA $10 \% / \mathrm{CH}_{2} \mathrm{Cl}_{2}, \mathrm{RT}, 6 \mathrm{~h}$.

The study performed by Innocente and collaborators [50] was useful to inspire the synthesis and antiplasmodial assessment of novel BA piperazinyl analogues, the results of which were published some years later [52]. Analogues $8\left(\mathrm{IC}_{50}=1 \mu \mathrm{M}\right)$ and $\mathbf{9}\left(\mathrm{IC}_{50}=4 \mu \mathrm{M}\right)$ (Scheme 6) displayed good antiplasmodial potency against the P. falciparum chloroquinesensitive 3D7 strain. Moreover, the authors investigated the mechanism of action of $\mathbf{8}$, and noted that this derivative led to an increase in cytosolic $\mathrm{Ca}^{2+}$ as well as causing a lower inhibition of $\beta$-haematin formation than that observed for chloroquine.

A new series of BA derivatives 10-18 obtained by carboxylic acid esterification at the $\mathrm{C}-3 \mathrm{OH}$ group was synthesized in an attempt to improve the antimalarial properties of the BA skeleton. Among the nine derivatives prepared (Figure 4), two presenting smaller side chains ( 15 and $16, \mathrm{IC}_{50}=5-8 \mu \mathrm{M}$ ) were found to be two to three times more potent than $\mathrm{BA}\left(\mathrm{IC}_{50}=18 \mu \mathrm{M}\right)$ against chloroquine-sensitive P. falciparum 3D7. Additionally, such analogues were non-cytotoxic towards the mammalian cell line HEK293T [53]. 

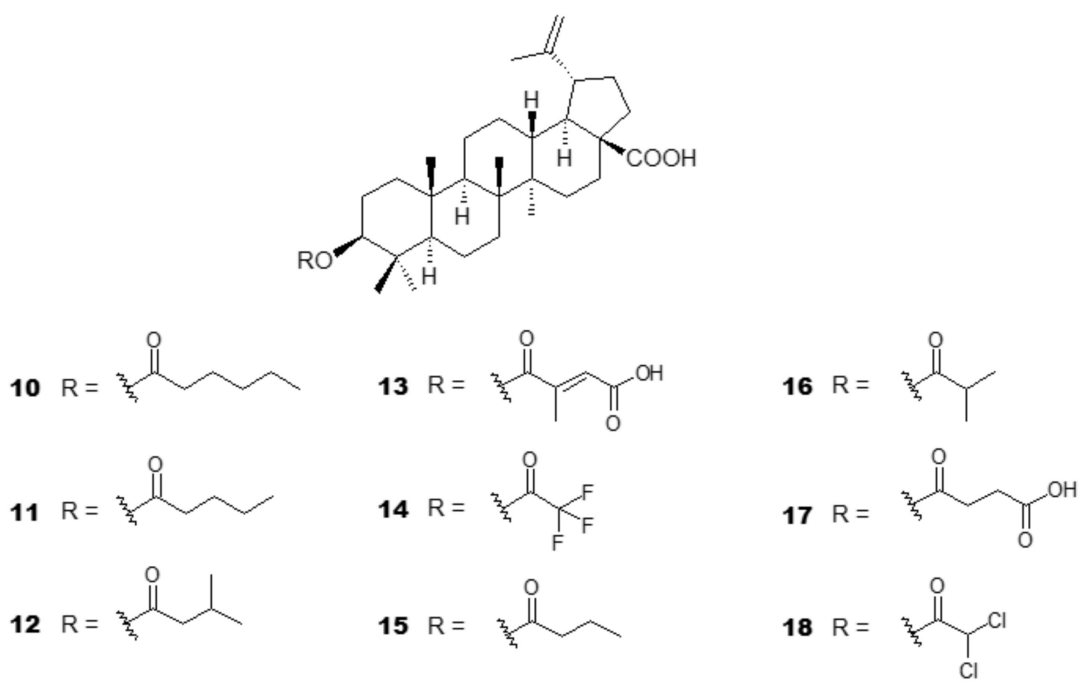

Figure 4. Antiplasmodial BA analogues from esterification at the $\mathrm{C}-3 \mathrm{OH}$ group.

In another study, the synthesis of a novel series of BA derivatives was performed by acetic, butyric and isobutyric esterification at the $\mathrm{C}-3 \mathrm{OH}$ group, as well as by incorporating methoxy and imidazole moieties at the carboxyl at the C-28 position [54]. The antiplasmodial activities of all analogues were assessed against the chloroquine-resistant P. falciparum W2 strain. The results permitted the conclusion that structural modifications at C-3 were more promising for increasing the antiplasmodial properties of the BA skeleton, rather than simultaneous modifications at the $C-3$ and $C-28$ positions. From all the prepared compounds, the ester derivative $3 \beta$-butanoyl betulinic acid (15) was shown to be the most potent $\left(\mathrm{IC}_{50}=3.4 \mu \mathrm{M}\right)$ and it also did not present cytotoxicity against VERO nor HepG2 cells $\left(\mathrm{CC}_{50}>400 \mu \mathrm{M}\right)$, thus displaying a selectivity index higher than 117. Docking studies indicated a possible interaction of $\mathbf{1 5}$ with the Plasmodium protease PfSUB1. Moreover, additional data suggest that the main target of $\mathbf{1 5}$ on Plasmodium might be related to other molecules and processes on the ring stage.

In a different chemical approach, nine 2,4-dinitrophenyl-hydrazono-BA analogues were prepared [55], but only compounds $19\left(\mathrm{IC}_{50}=15.3 \mu \mathrm{M}\right)$ and $20\left(\mathrm{IC}_{50}=10.2 \mu \mathrm{M}\right)$ (Figure 5) showed better antiplasmodial activity than $\mathrm{BA}\left(\mathrm{IC}_{50}=38.8 \mu \mathrm{M}\right)$ against the chloroquine-resistant $P$. falciparum W2 strain.
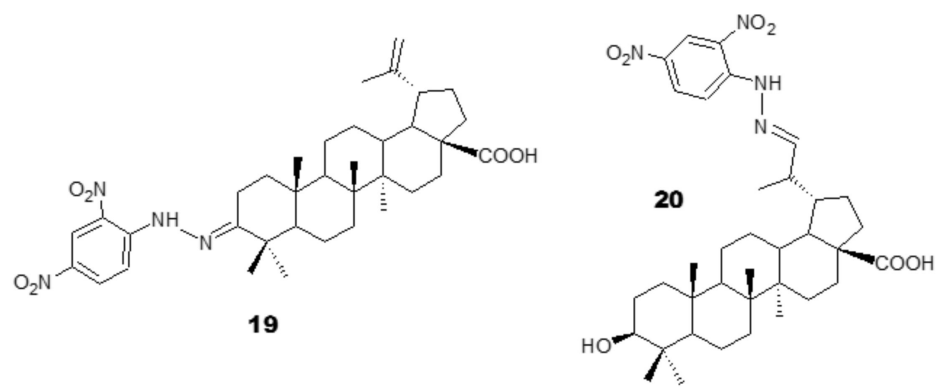

Figure 5. 2,4-Dinitrophenyl-hydrazone-BA analogues with moderate antiplasmodial activity.

Inspired by the highly active antimalarial compound ferroquine and by the previously prepared artemisinin-ferrocene hybrid, a series of BA/BE based dimer and hybrid compounds carrying ferrocene and/or artesunic acid moieties were designed and synthesized (Scheme 7), to include the ferrocene moiety into the new molecules as a linker or a subunit [56]. The antiplasmodial activity of all newly synthesized compounds $\mathbf{2 1 - 2 5}$ as well as the previously synthesized hybrids 26 and 27, were evaluated against $P$. falciparum 3D7 strain. Compounds $23\left(\mathrm{IC}_{50}=1.49 \mu \mathrm{M}\right), 26\left(\mathrm{IC}_{50}=0.26 \mu \mathrm{M}\right)$ and $27\left(\mathrm{IC}_{50}=0.09 \mu \mathrm{M}\right)$, which are hybrids of $\mathrm{BA}$ and artesunic acid, were found to be the most active antiplasmodial analogues. 

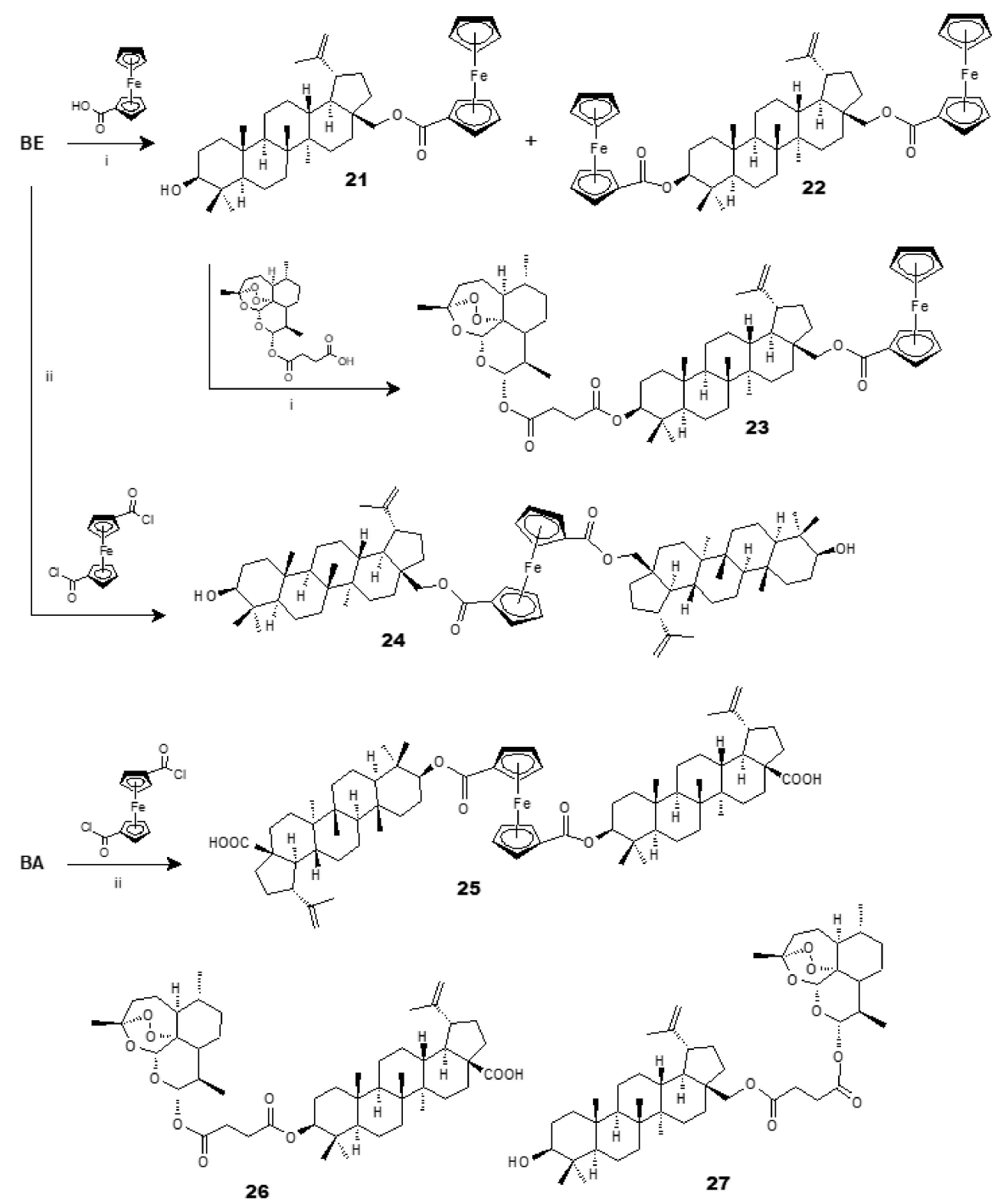

Scheme 7. Synthetic routes to BA/BE-derived dimers and hybrids 21-25. Reagents and conditions: (i) DCC, DMAP, $\mathrm{CH}_{2} \mathrm{Cl}_{2}, 0^{\circ} \mathrm{C} \rightarrow \mathrm{rt}$; (ii) $\mathrm{DMAP}, \mathrm{CH}_{2} \mathrm{Cl}_{2}, 0^{\circ} \mathrm{C} \rightarrow \mathrm{rt}$.

All the above described results indicated that BA is a weak antimalarial agent, and consequently, it is not suitable to be employed as a drug for this disease. However, the improvement in the antiplasmodial activity that was found for some of its derivatives makes BA a good starting material to design and prepare new analogues that are able to reach and even improve the potency of the commercially available antimalarial drugs. In this sense, new chemical approaches may explore other functionalities at the C-3 and /or C-28 positions in order to synthesize more potent antiplasmodial analogues. Within this scenario, hybridization with other antimalarial drugs seems to be a promising synthetic strategy.

\subsection{Antileishmanial Analogues}

Betulinal (BeAL) was the first naturally occurring BA-structurally related compound with antileishmanial properties to be reported in the literature. It showed a weak activity in vitro, reducing Leishmania amazonensis amastigotes infection by $88 \%$ at $136 \mu \mathrm{M}$, but this high dose was also significantly toxic to peritoneal macrophages [57]. However, the analogue 20(29)-dihydrobetulinic acid (DHBA) was described as being capable of 
strongly inhibiting the growth of $L$. donovani promastigotes $\left(\mathrm{IC}_{50}=2.6 \mu \mathrm{M}\right)$ and amastigotes $\left(\mathrm{IC}_{50}=4.1 \mu \mathrm{M}\right)$ at lower concentrations [58]. Furthermore, DHBA was also shown to be a dual inhibitor of DNA topoisomerases I and II and acts by preventing the formation of enzyme-DNA binary complex, thus inducing apoptosis.

Later, in a screening study aiming to investigate the in vitro leishmanicidal activity of 46 scarce natural products, the weak antileishmanial effect of $\mathrm{BA}\left(\mathrm{IC}_{50}=87.5 \mu \mathrm{M}\right)$ was then first evidenced against L. major promastigotes [59]. Similarly, betulinic acid acetate $\left(4, \mathrm{IC}_{50}=44.9 \mu \mathrm{M}\right)$ and $\mathrm{BoA}\left(\mathrm{IC}_{50}=51.2 \mu \mathrm{M}\right)$ derivatives were also both weakly active against L. amazonensis [45].

Heterocyclic analogues 28-34 were designed and synthesized from BE, employing BoA as a versatile intermediate. The employment of the cheap BE instead of BA is an advantage of this route. Different heterocycles were fused to the 2,3-position of the lupane skeleton, including isoxazole, pyrazine, pyridine, indole and pyrazole groups, while the carboxyl group at the C-28 position was also transformed into an amide derivative (Scheme 8). Among all compounds tested, the analogues $30\left(\mathrm{IC}_{50}=13.2 \mu \mathrm{M}\right)$ and $33\left(\mathrm{IC}_{50}=4.3 \mu \mathrm{M}\right)$ were found to display the best antileishmanial activity against axenic amastigotes of L. donovani, with derivative 33 being both the most potent and selective (SI = 12.9) antileishmanial analogue of all those reported in this study [60].

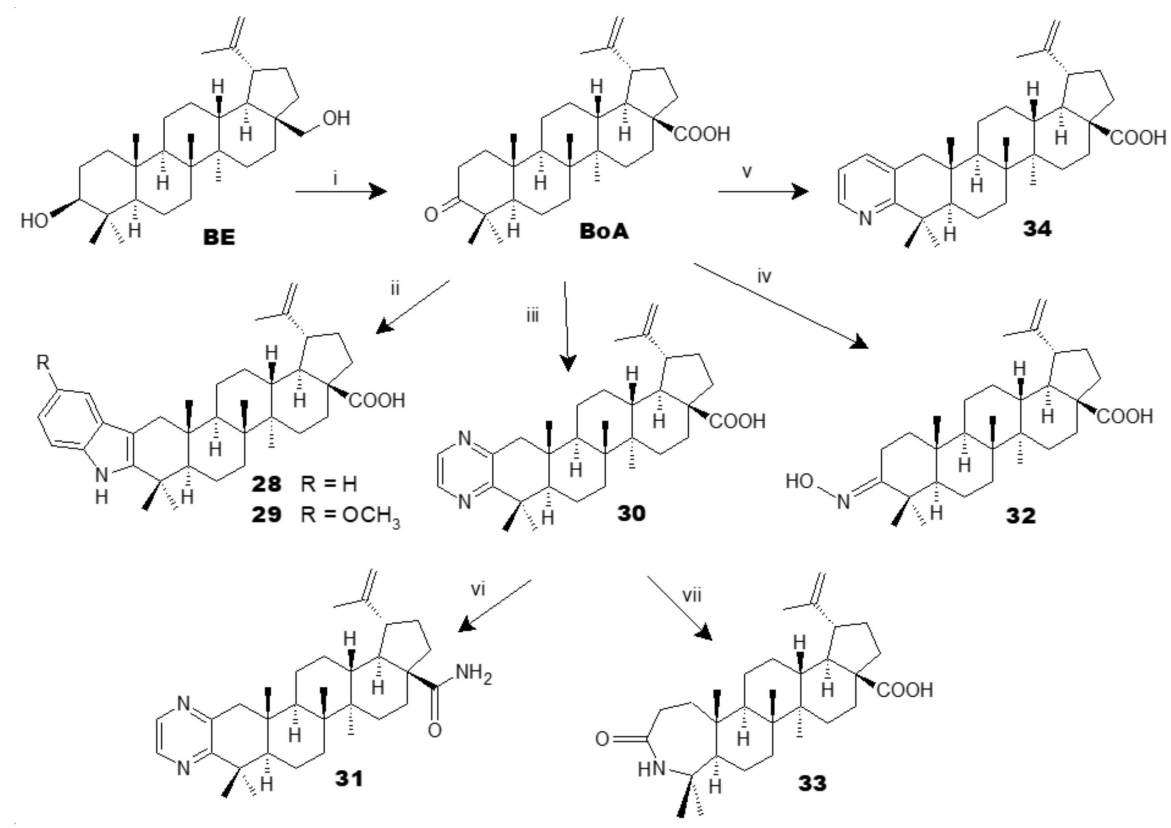

Scheme 8. Synthesis of heterocyclic BA analogues [60]. Reagents and conditions: (i) Jones oxidation, $\mathrm{Na}_{2} \mathrm{Cr}_{2} \mathrm{O}_{7}, \mathrm{H}_{2} \mathrm{SO}_{4}, \mathrm{H}_{2} \mathrm{O}$, acetone, rt, $21 \mathrm{~h}$ (44\%); (ii) appropriate phenylhydrazine hydrochloride, HOAc, reflux, $3 \mathrm{~h}$, (21-42\%); (iii) ethylenediamine, sulfur, morpholine, reflux, $21 \mathrm{~h}(68 \%)$; (iv) $\mathrm{NH}_{2} \mathrm{OH} / \mathrm{HCl}$, pyridine, $\mathrm{MeOH}$, reflux, $16 \mathrm{~h}(84 \%)$; (v) propargylamine, $\mathrm{Cu}(\mathrm{I}) \mathrm{Cl}, \mathrm{EtOH}$, reflux, $17 \mathrm{~h}(11 \%)$; (vi) 1. oxalyl chloride, DCM, rt, 3 h; 2 . aqueous ammonia, DCM, rt, $1 \mathrm{~h},(\sim 100 \%)$; (vii) TFAA, DCM, rt, 20 h, (33\%); DCM $\frac{1}{4}$ dichloromethane, TFAA $\frac{1}{4}$ trifluoroacetic anhydride.

The new imidazole carbamate and $N$-acylimidazole derivatives $35-40$ were synthesized from BoA (Scheme 9) and firstly, they were screened for in vitro cytotoxicity activity against human cancer cell lines [61]. Later, these imidazole analogues were also assessed against $L$. infantum promastigotes [62]. Compound $40\left(\mathrm{IC}_{50}=25.8 \mu \mathrm{M}\right)$, which has an additional imidazole carbamate at the C-2 position, was shown to be the most active analogue, and its antileishmanial activity was synergistically increased when $\mathbf{4 0}$ was associated with miltefosine, the medication used to treat leishmaniasis. 


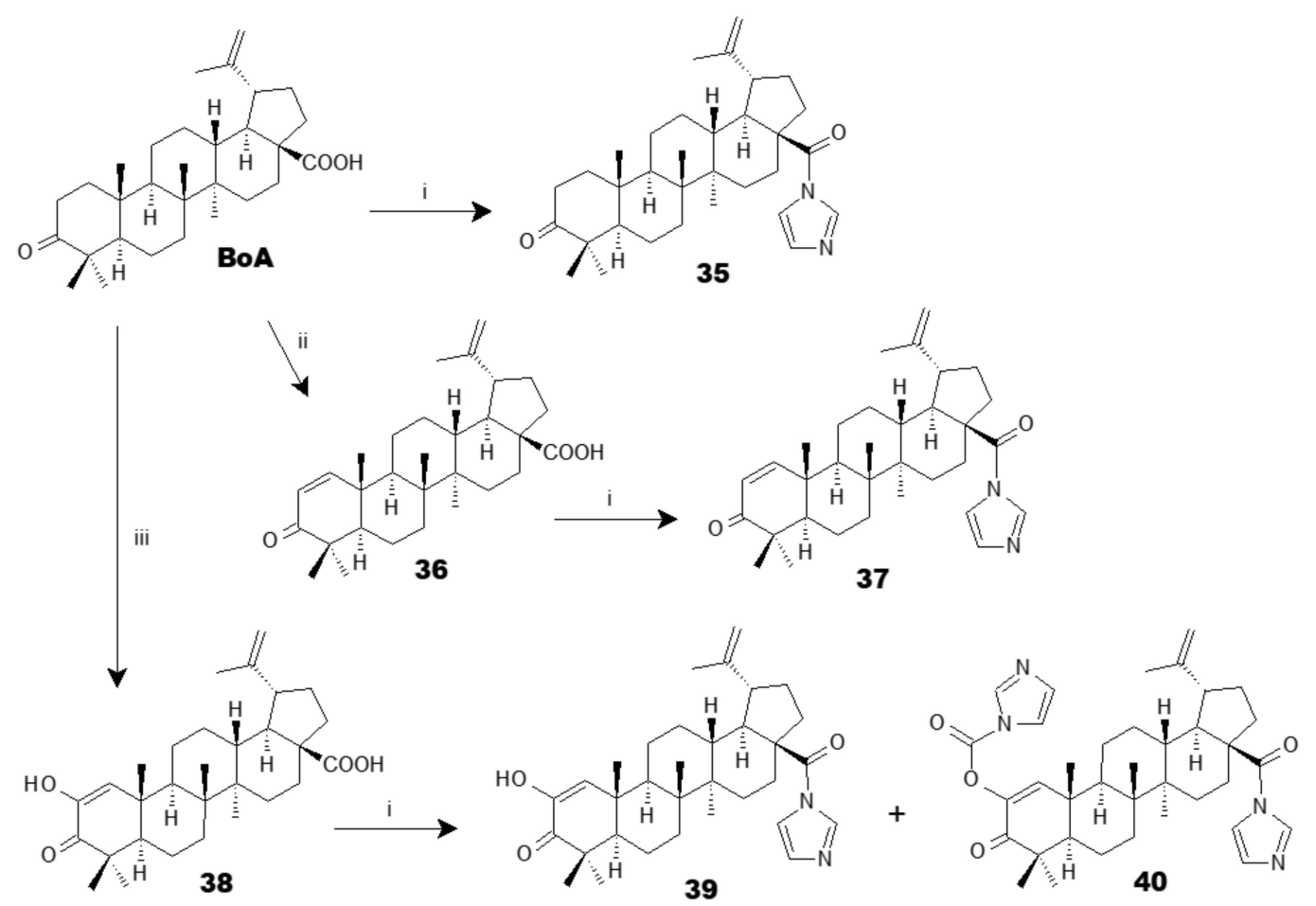

Scheme 9. Synthesis of imidazole BA analogues [61]. Reagents and conditions: (i) CDI, dry THF, $\mathrm{N}_{2}$, reflux, 8-9 h; (ii) DDQ, dioxane, $\mathrm{N}_{2}$, reflux, $15 \mathrm{~h}$; (iii) $\mathrm{O}_{2}$, $t$-BuOK, $t-\mathrm{BuOH}, 40^{\circ} \mathrm{C}, 2 \mathrm{~h}$.

Antileishmanial studies employing BA derivatives are still in early stages. Even though only a few results have been obtained up to the present time, they suggest that other known BA analogues may display interesting antileishmanial profiles and, thus, they also deserve to be assayed in vitro and in vivo against Leishmania sp. parasites, including in combination with traditional antileishmanial drugs. Furthermore, taking into account that heterocyclic betulin derivatives displayed antileishmanial activities with $\mathrm{GI}_{50}$ values between 8.9-30.0 $\mu \mathrm{M}$ [63], novel heterocyclic BA analogues are worthy of attention for synthesis and antileishmanial investigation.

\subsection{Antitrypanosomal Analogues}

BA shows weak antitrypanosomal properties, first revealed when this triterpene was isolated from a Strychnos spinose Lam. lipophilic leaf extract showing antitrypanosomal activity. This plant of the Loganiaceae family is traditionally used to treat African trypanosomiasis. The BA isolated was assayed against bloodstream forms of Trypanosoma brucei and showed $\mathrm{IC}_{50}=32.6 \mu \mathrm{M}(\mathrm{SI}=1.3)$ [64]. Subsequently, BA was also assayed against epimastigote forms of $T$. cruzi Tulahuen strain, and again BA was weakly active $\left(\mathrm{IC}_{50}=50.0 \mu \mathrm{M}\right)$ [45].

These findings indicated that BA could be considered a good lead for the design and synthesis of more potent and selective antitrypanosomal analogues [65]. Previous studies have suggested that changes at the C-28 carboxyl group could lead to analogues with enhanced antiprotozoal activities when compared to BA. Thus, new amide analogues 41-48 (Figure 6) were prepared and assayed against trypomastigotes forms of T. cruzi. The most potent antitrypanosomal effects were observed for $45\left(\mathrm{IC}_{50}=1.8 \mu \mathrm{M} ; \mathrm{SI}=17.3\right)$, $46\left(\mathrm{IC}_{50}=5.4 \mu \mathrm{M} ; \mathrm{SI}=5.3\right)$ and $48\left(\mathrm{IC}_{50}=5.0 \mu \mathrm{M} ; \mathrm{SI}=10.7\right)$, while BA displayed an $\mathrm{IC}_{50}$ value of $19.5 \mu \mathrm{M}$ and $\mathrm{SI}=1$. In this study, the authors identified 45 as a selective anti-T. cruzi agent, and additional experimental data showed this analogue destroys parasite cells by necrotic death and also exhibits synergistic activity when used in combination with benznidazole, the antiparasitic drug commonly employed in the treatment of Chagas disease [65]. 


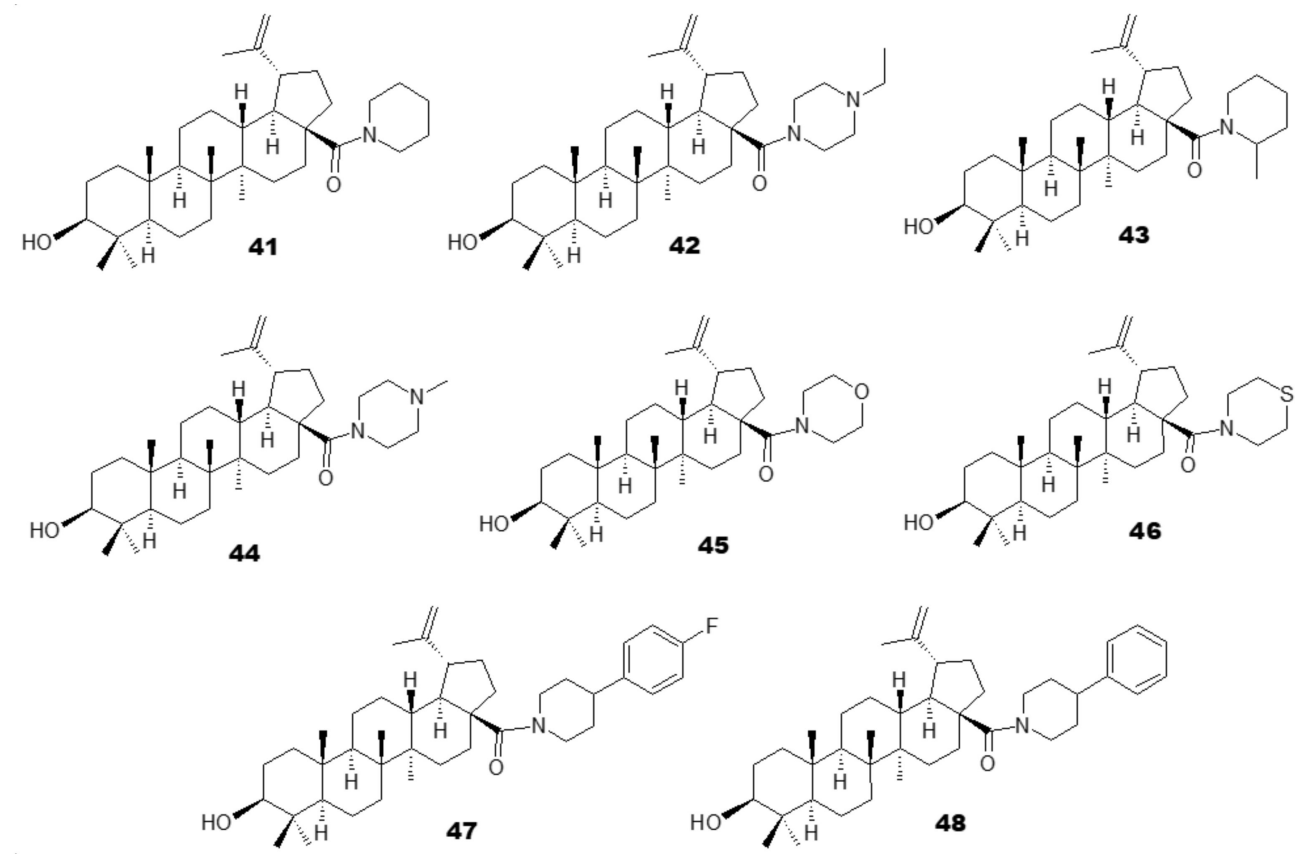

Figure 6. Amide BA analogues with antitrypanosomal activity.

These initial results reveal promising antitrypanosomal properties of BA analogues and open the door to unexplored opportunities for assaying numerous other BA derivatives that have already been synthesized $[66,67]$ against Trypanosoma $s p$. parasites. Moreover, new chemical approaches aiming at incorporating triphenylphosphonium groups into the BA skeleton [68] may improve not only physical properties, but also the mechanism of action of BA analogues, leading to more potent antitrypanosomal compounds.

\section{Concluding Remarks and Perspectives}

BA is a compound that is easily obtained from natural sources or by the chemical transformation of biosynthetically related triterpenes. Its total synthesis is still not commercially possible, but semisynthesis from BE has yielded good results. In addition, besides the already reported chemical procedures used to obtain BA and its derivatives from natural precursors, some promising biotechnological developments have also been achieved in the same direction by employing biocatalysis of $\mathrm{BE}$ and BA by microorganisms $[13,34,69-71]$ and plant cells [72].

BA and its derivatives present a range of biological activities, especially anticancer and anti-HIV properties. However, the antiprotozoal activity is also very interesting, particularly when dealing with vector-borne tropical diseases such as malaria, leishmaniases and trypanosomiases, which have a high prevalence in tropical and subtropical regions. The antiplasmodial activity described for BA was moderate, nevertheless some analogues that were acylated at the $\mathrm{C}-3$ position showed an improvement of this activity and the hybrid models with artesunic acid showed the most interesting properties. Similarly, several analogues also presented more intense antileishmanial activities than BA, and heterocycles fused to the $\mathrm{C}-2 / \mathrm{C}-3$ positions and amide derivatives were the most promising analogues. Regarding the antitrypanosomal activity and besides the weak activity of BA, some interesting antitrypanosomal analogues were also prepared by amide formation at the C-28 carboxylic group of the lupane skeleton.

To date, most of the chemical transformations performed on the BA structure deal with esterification of the C-3 hydroxyl group and derivatization of the C-28 carboxylic group, however, another functional group present in BA that is susceptible to transformation is the double bond at C-20/C-29. This has not been well explored, and no robust studies aimed at synthesizing BA antiparasitic analogs from structural modifications at these positions have been found in the literature yet. Just one recently published study 
suggested that BA bromination at the C-20/C-29 positions may generate more potent antileishmanial analogues [73]. In our opinion, further studies would be of interest to obtain new derivatives by transformation not only of the double bond itself, but also of the allylic positions. Its evaluation as an antiprotozoal would allow for gaining more in-depth knowledge regarding the structure-activity relationships of BA.

It is well known that molecular conjugation or hybridization can yield compounds with improved pharmacokinetic and pharmacological properties, and even overcome resistance in comparison with their precursors [74-76]. In this sense, taking into account that hybridization of BA with artesunic acid gave good results, it will be worth exploring the application of this strategy to other known antimalarial, antileishmanial and antitrypanosomal agents.

BA can be produced either by isolation of different plant extracts or by the chemical transformation of betulin; easily obtained from Betula ssp. Consequently, it can be said that BA could be a lead molecule of great interest for further research into obtaining new commercial products, with the potential to be used as antiprotozoal agents, including for the treatment of neglected tropical diseases.

Author Contributions: Conceptualization, R.B., J.M.D. and M.Á.C.; software, R.B. and A.B.C.; writing—original draft preparation, A.B.C., R.B., J.M.D. and M.Á.C.; writing—review and editing, A.B.C., R.B., J.M.D. and M.Á.C.; visualization, R.B. and J.M.D.; supervision, R.B., J.M.D. and M.Á.C. All authors have read and agreed to the published version of the manuscript.

Funding: This research was funded by Conselho Nacional de Desenvolvimento Científico e Tecnológico (CNPq), grant number \# 406427/2018-6.

Acknowledgments: The authors thank CAPES and CNPq for the scholarship.

Conflicts of Interest: The authors declare no conflict of interest. The funders had no role in the design of the study; in the collection, analyses, or interpretation of data; in the writing of the manuscript, or in the decision to publish the results.

\section{References}

1. Robertson, A.; Soliman, G.; Owen, E.C. Polyterpenoid compounds. Part, I. Betulic acid from Cornus florida L. J. Chem. Soc. 1939, 1267-1273. [CrossRef]

2. Kawaguti, R.; Kim, K.W. The constituents of Zyzyphus vulgaris Lamark var. spinosus Bunge. II. Betulinic acid. Yakugaku Zasshi 1940, 60, 595-596. [CrossRef]

3. Bruckner, G.J.; Kovacs, J.; Koczka, I. Occurrence of betulinic acid in the bark of the plane tree. J. Chem. Soc. 1948, $948-951$. [CrossRef]

4. Ralph, C.S.; White, D.E. Betulic acid from Syncarpia laurifolia. J. Chem. Soc. 1949, 3433-3434. [CrossRef]

5. Retzlaff, F. Ueber Herba gratiolae. Arch. Pharm. (Weinh.). 1902, 240, 561-568. [CrossRef]

6. Zellner, J.; Fajner, R. Wachsbestandteile in Hartriegelrinden (Cornaceae). Monatshefte 1925, 46, 611-630. [CrossRef]

7. Stabursvik, A. Occurrence of betulinic acid in Menyanthes trifoliata L. Acta Chem. Scand. 1953, 7, 446-447. [CrossRef]

8. Pai, S.R.; Joshi, R.K. Distribution of betulinic acid in plant kingdom. Plant. Sci. Today 2014, 1, 103-107. [CrossRef]

9. Pavanasasivam, G.; Sultanbawa, M.U.S. Betulinic acid in the dilleniaceae and a review of its natural distribution. Phytochemistry 1974, 13, 2002-2006. [CrossRef]

10. David, J.M.; Souza, J.C.; Guedes, M.L.S.; David, J.P. Estudo fitoquimico de Davilla rugosa: Flavonóides e terpenóides. Braz. J. Pharmacogn. 2006, 16, 105-108. [CrossRef]

11. Moghaddam, M.G.; Ahmad, F.B.H. Various botanical sources of betulinic acid: A review. Asian J. Chem. 2012, 24, 4843-4846.

12. Fukushima, E.O.; Seki, H.; Ohyama, K.; Ono, E.; Umemoto, N.; Mizutani, M.; Saito, K.; Muranaka, T. CYP716A subfamily members are multifunctional oxidases in triterpenoid biosynthesis. Plant. Cell Physiol. 2011, 52, 2050-2061. [CrossRef] [PubMed]

13. Zhou, C.; Li, J.; Li, C.; Zhang, Y. Improvement of betulinic acid biosynthesis in yeast employing multiple strategies. BMC Biotechnol. 2016, 16, 1-9. [CrossRef]

14. Trumbull, E.R.; Bianchi, E.; Eckert, D.J.; Wiedhopf, R.M.; Cole, J.R. Tumor inhibitory agents from Vauquelinia corymbosa (Rosaceae). J. Pharm. Sci. 1976, 65, 1407-1408. [CrossRef]

15. Pisha, E.; Chai, H.; Lee, I.-S.; Chagwedera, T.E.; Farnsworth, N.R.; Cordell, G.A.; Beecher, C.W.W.; Fong, H.H.S.; Kinghorn, A.D.; Brown, D.M.; et al. Discovery of betulinic acid as a selective inhibitor of human melanoma that functions by induction of apoptosis. Nat. Med. 1995, 1, 1046-1051. [CrossRef] [PubMed]

16. Zhang, D.; Xu, H.; Wang, L.; Li, Y.; Sun, P.; Wu, X.; Wang, G.; Chen, W.; Ye, W. Betulinic Acid and its Derivatives as Potential Antitumor Agents. Harv. Bus. Rev. 2008, 86, 84-92. [CrossRef] 
17. Zhang, X.; Hu, J.; Chen, Y. Betulinic acid and the pharmacological effects of tumor suppression (Review). Mol. Med. Rep. 2016, 14, 4489-4495. [CrossRef]

18. Hoenke, S.; Heise, N.V.; Kahnt, M.; Deigner, H.P.; Csuk, R. Betulinic acid derived amides are highly cytotoxic, apoptotic and selective. Eur. J. Med. Chem. 2020, 207, 112815. [CrossRef]

19. Huang, Q.; Chen, H.; Luo, X.; Zhang, Y.; Yao, X.; Zheng, X. Structure and Anti-HIV Activity of Betulinic Acid Analogues. Curr. Med. Sci. 2018, 38, 387-397. [CrossRef]

20. Wu, H.F.; Morris-Natschke, S.L.; Xu, X.D.; Yang, M.H.; Cheng, Y.Y.; Yu, S.S.; Lee, K.H. Recent advances in natural anti-HIV triterpenoids and analogs. Med. Res. Rev. 2020, 40, 2339-2385. [CrossRef]

21. Wang, Q.; Li, Y.; Zheng, L.; Huang, X.; Wang, Y.; Chen, C.H.; Cheng, Y.Y.; Morris-Natschke, S.L.; Lee, K.H. Novel Betulinic Acid-Nucleoside Hybrids with Potent Anti-HIV Activity. Acs Med. Chem. Lett. 2020, 11, 2290-2293. [CrossRef]

22. Ghaffari Moghaddam, M.; Bin, H.; Ahmad, F.; Samzadeh-Kermani, A. Biological Activity of Betulinic Acid: A Review. Pharmacol. Pharm. 2012, 03, 119-123. [CrossRef]

23. Ríos, J.L.; Máñez, S. New Pharmacological Opportunities for Betulinic Acid. Planta Med. 2018, 84, 8-19. [CrossRef] [PubMed]

24. Hordyjewska, A.; Ostapiuk, A.; Horecka, A.; Kurzepa, J. Betulin and betulinic acid: Triterpenoids derivatives with a powerful biological potential. Phytochem. Rev. 2019, 18, 929-951. [CrossRef]

25. Saccoliti, F.; Di Santo, R.; Costi, R. Recent Advancement in the Search of Innovative Antiprotozoal Agents Targeting Trypanothione Metabolism. ChemMedChem 2020, 1-17. [CrossRef] [PubMed]

26. Sarma, N.; Patouillard, E.; Cibulskis, R.E.; Arcand, J.L. The economic burden of Malaria: Revisiting the evidence. Am. J. Trop. Med. Hyg. 2019, 101, 1405-1415. [CrossRef]

27. World Health Organization. Malaria. Available online: https://www.who.int/health-topics/malaria\#tab=tab_1 (accessed on 15 December 2020).

28. World Health Organization. Leishmaniasis. Available online: https://www.who.int/health-topics/leishmaniasis\#tab=tab_1 (accessed on 15 December 2020).

29. World Health Organization. Human African Trypanosomiasis (Sleeping Sickness). Available online: https:/ /www.who.int/ health-topics/human-african-trypanosomiasis\#tab=tab_1 (accessed on 15 December 2020).

30. World Health Organization. Chagas Disease (American Trypanosomiasis). Available online: https://www.who.int/healthtopics / chagas-disease\#tab=tab_1 (accessed on 15 December 2020).

31. Manner, C.K.; Graef, K.M.; Dent, J. WIPO Re:Search: Catalyzing public-private partnerships to accelerate tropical disease drug discovery and development. Trop. Med. Infect. Dis. 2019, 4, 53. [CrossRef]

32. Bernal, F.A.; Kaiser, M.; Wünsch, B.; Schmidt, T.J. Structure-Activity Relationships of Cinnamate Ester Analogues as Potent Antiprotozoal Agents. ChemMedChem 2020, 15, 68-78. [CrossRef]

33. Chen, Q.-h.; Liu, J.; Zhang, H.-f.; He, G.-q.; Fu, M.-l. The betulinic acid production from betulin through biotransformation by fungi. Enzym. Microb. Technol. 2009, 45, 175-180. [CrossRef]

34. Liu, J.; Fu, M.L.; Chen, Q.H. Biotransformation optimization of betulin into betulinic acid production catalysed by cultured Armillaria luteo-virens Sacc ZJUQH100-6 cells. J. Appl. Microbiol. 2011, 110, 90-97. [CrossRef]

35. An, T.; Zha, W.; Zi, J. Biotechnological production of betulinic acid and derivatives and their applications. Appl. Microbiol. Biotechnol. 2020, 104, 3339-3348. [CrossRef] [PubMed]

36. Stork, G.; Uyeo, S.; Wakamatsu, T.; Grieco, P.; Labovitz, J. The Total Synthesis of Lupeol. J. Am. Chem. Soc. 1971, 93, 4945-4947. [CrossRef]

37. Surendra, K.; Corey, E.J. A short enantioselective total synthesis of the fundamental pentacyclic triterpene lupeol. J. Am. Chem. Soc. 2009, 131, 13928-13929. [CrossRef]

38. Kim, D.S.H.L.; Chen, Z.; Van Nguyen, T.; Pezzuto, J.M.; Qiu, S.; Lu, Z.Z. A concise semi-synthetic approach to betulinic acid from betulin. Synth. Commun. 1997, 27, 1607-1612. [CrossRef]

39. Laszczyk, M.N. Pentacyclic triterpenes of the lupane, oleanane and ursane group as tools in cancer therapy. Planta Med. 2009, 75, 1549-1560. [CrossRef] [PubMed]

40. Csuk, R.; Schmuck, K.; Schäfer, R. A practical synthesis of betulinic acid. Tetrahedron Lett. 2006, 47, 8769-8770. [CrossRef]

41. Ruzicka, L.; Lamberton, A.H.; Christie, E.W. Zur Kenntnis der Triterpene. 41. Mitteilung. Oxydation des Betulin-mono-acetats mit Chromtrioxyd zu sauren Produkten. Helv. Chim. Acta 1938, 1706-1717. [CrossRef]

42. Baltina, L.A.; Flekhter, O.B.; Nigmatullina, L.R.; Boreko, E.I.; Pavlova, N.I.; Nikolaeva, S.N.; Savinova, O.V.; Tolstikov, G.A. Lupane triterpenes and derivatives with antiviral activity. Bioorganic Med. Chem. Lett. 2003, 13, 3549-3552. [CrossRef]

43. Pichette, A.; Liu, H.; Roy, C.; Tanguay, S.; Simard, F.; Lavoie, S. Selective oxidation of betulin for the preparation of betulinic acid, an antitumoral compound. Synth. Commun. 2004, 34, 3925-3937. [CrossRef]

44. Wickholm, N.; Alakurtti, S.; Yli-Kauhaluoma, J.; Koskimies, J. Method for preparation of betulinic acid 2013. WO2013038316A1, 21 March 2013.

45. Domínguez-Carmona, D.B.; Escalante-Erosa, F.; García-Sosa, K.; Ruiz-Pinell, G.; Gutierrez-Yapu, D.; Chan-Bacab, M.J.; Giménez-Turba, A.; Peña-Rodríguez, L.M. Antiprotozoal activity of Betulinic acid derivatives. Phytomedicine 2010, 17, $379-382$. [CrossRef] 
46. Bringmann, G.; Saeb, W.; Assi, L.A.; François, G.; Narayanan, A.S.S.; Peters, K.; Peters, E.-M. Betulinic acid: Isolation from Triphyophyllum peltatum and Ancistrocladus heyneanus, antimalarial activity, and crystal structure of the benzyl ester. Planta Med. 1997, 63, 255-257. [CrossRef] [PubMed]

47. Steele, J.; Warhurst, D.; Kirby, G.; Simmonds, M. In vitro and in vivo evaluation of betulinic acid as an antimalarial. Phyther. Res. 1999, 13, 115-119. [CrossRef]

48. Ziegler, H.L.; Franzyk, H.; Sairafianpour, M.; Tabatabai, M.; Tehrani, M.D.; Bagherzadeh, K.; Hägerstrand, H.; Stærk, D.; Jaroszewski, J.W. Erythrocyte membrane modifying agents and the inhibition of Plasmodium falciparum growth: Structureactivity relationships for betulinic acid analogues. Bioorganic Med. Chem. 2004, 12, 119-127. [CrossRef]

49. De Sá, M.S.; Costa, J.F.O.; Krettli, A.U.; Zalis, M.G.; De Azevedo Maia, G.L.; Sette, I.M.F.; De Amorim CâMara, C.; Filho, J.M.B.; Giulietti-Harley, A.M.; Ribeiro Dos Santos, R.; et al. Antimalarial activity of betulinic acid and derivatives in vitro against Plasmodium falciparum and in vivo in P. berghei-infected mice. Parasitol. Res. 2009, 105, 275-279. [CrossRef]

50. Innocente, A.M.; Silva, G.N.S.; Cruz, L.N.; Moraes, M.S.; Nakabashi, M.; Sonnet, P.; Gosmann, G.; Garcia, C.R.S.; Gnoatto, S.C.B. Synthesis and antiplasmodial activity of betulinic acid and ursolic acid analogues. Molecules 2012, 17, 12003-12014. [CrossRef]

51. Diedrich, D.; Wildner, A.C.; Silveira, T.F.; Silva, G.N.S.; dos Santos, F.; da Silva, E.F.; do Canto, V.P.; Visioli, F.; Gosmann, G.; Bergold, A.M.; et al. SERCA plays a crucial role in the toxicity of a betulinic acid derivative with potential antimalarial activity. Chem. Biol. Interact. 2018, 287, 70-77. [CrossRef] [PubMed]

52. Silva, G.N.S.; Schuck, D.C.; Cruz, L.N.; Moraes, M.S.; Nakabashi, M.; Gosmann, G.; Garcia, C.R.S.; Gnoatto, S.C.B. Investigation of antimalarial activity, cytotoxicity and action mechanism of piperazine derivatives of betulinic acid. Trop. Med. Int. Heal. 2015, 20, 29-39. [CrossRef]

53. Da Silva, G.N.S.; Maria, N.R.G.; Schuck, D.C.; Cruz, L.N.; De Moraes, M.S.; Nakabashi, M.; Graebin, C.; Gosmann, G.; Garcia, C.R.S.; Gnoatto, S.C.B. Two series of new semisynthetic triterpene derivatives: Differences in anti-malarial activity, cytotoxicity and mechanism of action. Malar. J. 2013, 12, 1-7. [CrossRef]

54. Cargnin, S.T.; Staudt, A.F.; Medeiros, P.; de Medeiros Sol Sol, D.; de Azevedo dos Santos, A.P.; Zanchi, F.B.; Gosmann, G.; Puyet, A.; Garcia Teles, C.B.; Gnoatto, S.B. Semisynthesis, cytotoxicity, antimalarial evaluation and structure-activity relationship of two series of triterpene derivatives. Bioorganic Med. Chem. Lett. 2018, 28, 265-272. [CrossRef]

55. Ullah, A.; Baratto, L.C.; Paula, R.C.; Silva, L.H.V.; Soares, M.J.; Oliveira, B.H. Preparation of derivatives of betulinic acid, steviol and isosteviol and evaluation of antitrypanosomal and antimalarial activities. J. Braz. Chem. Soc. 2016, 27, 1245-1253. [CrossRef]

56. Karagöz, A.Ç.; Leidenberger, M.; Hahn, F.; Hampel, F.; Friedrich, O.; Marschall, M.; Kappes, B.; Tsogoeva, S.B. Synthesis of new betulinic acid/betulin-derived dimers and hybrids with potent antimalarial and antiviral activities. Bioorganic Med. Chem. 2019, 27, 110-115. [CrossRef] [PubMed]

57. Sauvain, M.; Kunesch, N.; Poisson, J.; Gantier, J.C.; Gayral, P.; Dedet, J.P. Isolation of leishmanicidal triterpenes and lignans from the amazonian liana Doliocarpus dentatus (Dilleniaceae). Phyther. Res. 1996, 10, 1-4. [CrossRef]

58. Chowdhury, A.R.; Mandal, S.; Goswami, A.; Ghosh, M.; Mandal, L.; Chakraborty, D.; Ganguly, A.; Tripathi, G.; Mukhopadhyay, S.; Bandyopadhyay, S.; et al. Dihydrobetulinic acid induces apoptosis in Leishmania donovani by targeting DNA topoisomerase I and II: Implications in antileishmanial therapy. Mol. Med. 2003, 9, 26-36. [CrossRef]

59. Takahashi, M.; Fuchino, H.; Sekita, S.; Satake, M. In vitro leishmanicidal activity of some scarce natural products. Phyther. Res. 2004, 18, 573-578. [CrossRef]

60. Haavikko, R.; Nasereddin, A.; Sacerdoti-Sierra, N.; Kopelyanskiy, D.; Alakurtti, S.; Tikka, M.; Jaffe, C.L.; Yli-Kauhaluoma, J. Heterocycle-fused lupane triterpenoids inhibit Leishmania donovani amastigotes. Medchemcomm 2014, 5, 445-451. [CrossRef]

61. Santos, R.C.; Salvador, J.A.R.; Marín, S.; Cascante, M. Novel semisynthetic derivatives of betulin and betulinic acid with cytotoxic activity. Bioorganic Med. Chem. 2009, 17, 6241-6250. [CrossRef] [PubMed]

62. Sousa, M.C.; Varandas, R.; Santos, R.C.; Santos-Rosa, M.; Alves, V.; Salvador, J.A.R. Antileishmanial activity of semisynthetic lupane triterpenoids betulin and betulinic acid derivatives: Synergistic effects with miltefosine. PLoS ONE 2014, 9, e89939. [CrossRef] [PubMed]

63. Alakurtti, S.; Heiska, T.; Kiriazis, A.; Sacerdoti-Sierra, N.; Jaffe, C.L.; Yli-Kauhaluoma, J. Synthesis and anti-leishmanial activity of heterocyclic betulin derivatives. Bioorganic Med. Chem. 2010, 18, 1573-1582. [CrossRef]

64. Hoet, S.; Pieters, L.; Muccioli, G.G.; Habib-Jiwan, J.L.; Opperdoes, F.R.; Quetin-Leclercq, J. Antitrypanosomal activity of triterpenoids and sterols from the leaves of Strychnos spinosa and related compounds. J. Nat. Prod. 2007, 70, 1360-1363. [CrossRef] [PubMed]

65. Meira, C.S.; Barbosa-Filho, J.M.; Lanfredi-Rangel, A.; Guimarães, E.T.; Moreira, D.R.M.; Soares, M.B.P. Antiparasitic evaluation of betulinic acid derivatives reveals effective and selective anti-Trypanosoma cruzi inhibitors. Exp. Parasitol. 2016, 166, 108-115. [CrossRef]

66. Borkova, L.; Hodon, J.; Urban, M. Synthesis of Betulinic Acid Derivatives with Modified A-Rings and their Application as Potential Drug Candidates. Asian J. Org. Chem. 2018, 7, 1542-1560. [CrossRef]

67. Hodon, J.; Borkova, L.; Pokorny, J.; Kazakova, A.; Urban, M. Design and synthesis of pentacyclic triterpene conjugates and their use in medicinal research. Eur. J. Med. Chem. 2019, 182, 1-25. [CrossRef] [PubMed]

68. Grymel, M.; Zawojak, M.; Adamek, J. Triphenylphosphonium Analogues of Betulin and Betulinic Acid with Biological Activity: A Comprehensive Review. J. Nat. Prod. 2019, 82, 1719-1730. [CrossRef] [PubMed] 
69. Feng, Y.; Li, M.; Liu, J.; Xu, T.Y.; Fang, R.S.; Chen, Q.H.; He, G.Q. A novel one-step microbial transformation of betulin to betulinic acid catalysed by Cunninghamella blakesleeana. Food Chem. 2013, 136, 73-79. [CrossRef]

70. Chatterjee, P.; Kouzi, S.A.; Pezzuto, J.M.; Hamann, M.T. Biotransformation of the antimelanoma agent betulinic acid by Bacillus megaterium ATCC 13368. Appl. Environ. Microbiol. 2000, 66, 3850-3855. [CrossRef] [PubMed]

71. Wu, J.; Niu, Y.; Bakur, A.; Li, H.; Chen, Q. Cell-free production of pentacyclic triterpenoid compound betulinic acid from betulin by the engineered Saccharomyces cerevisiae. Molecules 2017, 22, 1075. [CrossRef] [PubMed]

72. Häkkinen, S.T.; Nygren, H.; Maiorova, N.; Haavikko, R.; Alakurtti, S.; Yli-Kauhaluoma, J.; Rischer, H.; Oksman-Caldentey, K.M. Biotransformation of Cyclodextrine-Complexed Semisynthetic Betulin Derivatives by Plant Cells. Planta Med. 2018, 84, 743-748. [CrossRef]

73. Cargnin, S.T.; Staudt, A.F.; Paula De Azevedo Dos Santos, A.; Gosmann, G.; Bioni, C.; Teles, G.; Gnoatto, S.B. Effective approach to semi-synthesis of lupane and ursane brominated derivatives and its effects on viability of Leishmania amazonensis. Ann. Med. Chem. Res. 2017, 3, 1-5.

74. Tietze, L.F.; Bell, H.P.; Chandrasekhar, S. Natural product hybrids as new leads for drug discovery. Angew. Chem. Int. Ed. 2003, 42, 3996-4028. [CrossRef]

75. Ojima, I. Modern Molecular Approaches to Drug Design and Discovery. Acc. Chem. Res. 2008, 41, 2-3. [CrossRef] [PubMed]

76. Bansal, Y.; Silakari, O. Multifunctional compounds: Smart molecules for multifactorial diseases. Eur. J. Med. Chem. 2014, 76, 31-42. [CrossRef] [PubMed] 